\title{
LEGAL STATUS OF EMPLOYMENT OF BOARD MEMBERS IN COMPANIES IN THE REPUBLIC OF CROATIA
}

\author{
Mladen Kršnjavi, univ. spec. iur.*
}

\begin{abstract}
In this paper, the author interprets domestic legal regulations related to the organization of legal status of employment of board members and contractual relationship of board members with the companies and gives a general review of organization of legal status of employment of board members in companies in the Republic of Croatia. For the purpose of company management, it is possible to conclude the Employment Contract between the board member and the company or special contractual relationship based on obligation right which is not an employment relationship. The paper will elaborate the differences between the aforementioned contracts, as well as the issue whether the board members are workers or not and enjoying the full protection according to the provisions of the Labour Act.
\end{abstract}

Furthermore, based on case law examples of the subject matter jurisdiction of the courts in the Republic of Croatia, the author will try to give answers to some legal questions in the context of management contracts.

KEYWORDS: legal status of employment of board members in companies, management contract, employment contract, company management

\section{INTRODUCTION}

In order to provide full functioning of the company board member related to the company management, the latter must be provided with certain stability, i.e. safety, primarily status and financial. When observing the legal status of employment of board members, it is required to indicate to the fact of existing

* Head of the legal, administrative and technical tasks department of Archaeological museum in Zagreb; mkrsnjavi@amz.hr. 
two separate legal relations ${ }^{1}$. Legal relation which regulates the rights and obligations of the board member in the company organ structure is of status nature (it is based on appointment decision), while the legal relation which regulates the rights and obligations between the board member and the company is of obligation-legal nature ${ }^{2}$.

\section{EMPLOYMENT CONTRACT OR SPECIAL CONTRACTUAL RELATIONSHIP BASED ON OBLIGATION RIGHT - A MANAGEMENT CONTRACT}

As regarding the regulation of rights and obligations between the board member and the company related to the company management, it is possible to conclude the Employment Contract or special contractual relationship based on obligation right which is not an employment relationship ${ }^{3}$. Such contractual relationship is called a management contract ${ }^{4}$. Management contract is an informal contract, consensual, bilaterally obliged, personal contract ${ }^{5}$, which can be chargeable or free of charge. The case law defines the management contract as the obligation law contract with elements of the temporary service contract and/or labour contract ${ }^{6}$.

\footnotetext{
There are exceptions as well. Thus, for example, in Article 50 paragraph 7 of the Insurance Act (Official Gazette No. 30/15) it is stipulated that board members in order to be insured must be full-time employed. The same is stipulated in Article 37 of the Credit Institutions Act (Official Gazette No. 159/13 and 19/15).

2 Potočnjak, Ž.: Pravno uređenje rada članova uprava za društva kapitala (Legal Regulation of Employment of Members of Boards in Companies), Pravo u gospodarstvu No. 3/ 2008, p. 424.

3 The Republic of Croatia Supreme Court judgement No. Revr. 666/04-2, 23.2.2005., available at http://sudska praksa.vsrh.hr - "... management contract is not based on provisions of the Labour Act but on provisions of the Obligations Act."

4 In international business practise, the term "management contract" considers typical unnominated contract based on which the company management, which is usually carried out by the company board, is entrusted to another company which is paid to carry out the management function. Refer to Grgurev, I.: Pravna priroda i sadržaj menadžerskih ugovora, Rasip d.o.o., 2011., p. 14.

5 Gregurić, M.,Turković-Jarža, L.: Menadžerski ugovor, Računovodstvo, revizija i financije, No. 10/2000, p. 101 / Order Contract Article 763 - 784 of the Obligations Act (Official Gazette No. $35 / 05,48 / 08$ and $78 / 15$ )

6 The Republic of Croatia Supreme Court judgement No. Revr. 283/03-2, 25.9.2003. - The contract in subject is the management contract by its legal nature, which is not based on provisions of the Labour Act but on provisions of the Obligations Act with certain elements of the temporary service contract.
} 
Pursuant to Article 10 paragraph 1 of the Labour $\operatorname{Act}^{7}$ (hereinafter referred to as LA), the employment relationship is established by concluding the employment contract. If it concerns the employment relationship, their relationship is judged solely according to the provisions of $\mathrm{LA}^{8}$. However, precisely due to a fact that it concerns the persons who contribute to achieving the company objectives by their knowledge, know-how, organizational and other capabilities, such relationship should be regulated on different legal basis. Pursuant to Article 4 paragraph 3 of LA, it is stipulated that physical person, who is authorised to manage the employer duties as the board member, executive director or in another capacity according to the special law, solely or jointly, is entitled to carry out certain duties for employer as his worker, with restrictions in implementing certain provisions of the act set forth by the legislator. Provisions of LA related to the employment contract for a fixed term, termination of employment contract, notice period and severance pay are not applied to the aforementioned person. Furthermore, pursuant to Article 88 paragraph 3 of LA, it is stipulated that no provisions on the longest duration of weekly working hours, night work, break and daily and weekly leave are applied to the worker having the manager status if contracted an independency in determination with the employer. The difference between an "ordinary" worker and board member who carries out more complicate and demanding duties related to the company management is seen here.

In certain situations, a combination of these two contracts is possible when the contract has elements of the management contract and employment contract as well ${ }^{9}$. Which contract will be concluded and under which conditions with the appointed board member depends on the authorised body, while the content of the contract may be a subject to the negotiations between the company authorised body (usually the supervisory board) and board member. There are certain differences between the employment contract and management contract which must be taken into consideration when selecting the type of the contract, regardless the subject of obligation of each of them is labour itself.

It is primarily the question of time period to which certain contract is concluded. Employment contract is concluded for indefinite term and only in certain situations set forth in LA can be concluded for fixed term ${ }^{10}$, not more than three years, which termination is predetermined by objective reasons justified

\footnotetext{
7 'Official Gazette" No. 93/14

8 Refer to p. $3-7$

9 The Republic of Croatia Supreme Court judgement No. Revr:680/04-5, 28.11.2006. available at http://sudska praksa.vsrh.hr

10 Article 12 of LA
} 
by the term, by carrying out certain business activity or by appearance of certain event. The exception is that the employment contract for fixed term may last more than three years only if required so due to a replacement of temporary absent worker or in case when it is permitted by the law or collective agreement due to some other objective reasons. In case the employment contract for fixed term is concluded contrary to the provisions of LA or if worker continues to work for the employer even after the termination of the contract, it is considered to be concluded for indefinite term ${ }^{11}$. Since the case law did not take a stand that the employment contract of board member could be considered as an exception and that could be concluded for fixed term for more than three years, there is a danger that the employment contract may be transformed into the employment relation for indefinite term. Namely, pursuant to Article 244 paragraph 1 of the Companies $\mathrm{Act}^{12}$ (hereinafter referred to as CA), the board member is appointed for fixed term of not more than five years (with a possibility of reappointment), thus the contractual relationship is of limited term. However, in Article 4 of LA, it is clearly stipulated that no provisions of LA related to the employment contract for a fixed term, termination of employment contract, notice period and severance pay are applied to a physical person who is authorized to manage the employer duties as the board member and who is in employment relationship as worker.

The freedom of contracting permitted by the Civil Obligations Act $^{13}$ (hereinafter referred to as COA) provides for concluding the management contract for indefinite or fixed term, without any limitations regarding the longest time period on which the contract for fixed term could be concluded. Contractual parties should take account that the management contract would last even upon the termination of the board member mandate (by expiry, revocation or resignation). Therefore, it is required to foreseen and regulate the issue related to the situation when the mandate is terminated, and if such issue cannot be regulated, then the provisions of $\mathrm{COA}^{14}$ related to termination of the permanent obligation will be applied. It is thus more appropriate to conclude the contract on carrying out the board member duties for fixed term complied with the mandate term; however, even then it is necessary to foreseen a situation in case of early termination of board member mandate.

\footnotetext{
11 Article 12 paragraph 7 of LA

12 Companies Act ("Official Gazette" No. 111/93, 34/99, 121/09 - authentic interpretation, 52/00 - CCC Decision, 118/03, 107/2007, 146/08, 137/09, 152/11 - consolidated text, 111/12, $68 / 13$ and $110 / 15)$

13 Civil Obligations Act "Official Gazette" No. 35/05, 48/08 and 78/15; Act on Fulfilling the Monetary Obligation Terms "Official Gazette" No. 125/11 - Article 174 of COA is no longer valid

14 Article 212 of COA
} 
Furthermore, the issue of subordination (personal dependence) is set forth as crucial criterion when evaluating the legal nature of concluded contract between the board member and the company related to carrying out the board member duties, and in possibility of limited implementation of legal protection through LA standards which have been established in order to protect the workers as weaker parties. A dependence and subordination of worker towards employer and chargeability of his work represent one of the crucial elements of employment relationship ${ }^{15}$.

The work of board member requires independence ${ }^{16}$ (professional and organizational) in carrying out the company management duties without the guarantee of the final result. The lack of personal dependence means that there is no need for employment and legal protection of the board member. It does not mean that board members are not protected whatsoever, but it will depend on contractual clauses in the contract between the board member and the company, as well as in certain legal regulations (provisions of CA, LA, Civil Procedure Act) and case law $^{17}$. It is important to emphasize that independence

15 Grgurev, I.: Ugovor o službi - novi imenovani ugovor? Pravo u gospodarstvu (1330-5476) 40 (2001), 4; p. 273.

16 Horak, H., Dumančić, K.: Neovisnost i nagrađivanje članova nadzornih odbora i neizvršnih direktora, Zbornik Pravnog fakulteta u Splitu, y. 48, 1/2011., p. 33.-56.

17 In case Danosa (Judgement in case C-232/09 of 18 November 2010) a revoked pregnant sole member of the Board of Directors of a capital company stated that she should have been considered as worker within the meaning of Council Directive 92/85/EEC of 19 October 1992 on the introduction of measures to encourage improvements in the safety and health at work of pregnant workers and workers who have recently given birth or are breastfeeding and that legal provision contained in the Latvian regulation, which provides for revocation of pregnant member of the Board of Directors of a capital company without any restrictions, is not complied with Article 10 paragraph 1 of the aforementioned Directive, which requires the EU Members States to prohibit the dismissal of workers during the period from the beginning of their pregnancy to the end of the maternity leave. Accordingly, the case Danosa required the European Court to establish whether the member of the Board of Directors of a capital company should be considered as "worker" within the concept of EU legislation, as well as whether the provision of the Latvian Commercial Code pursuant to which the member of the Board of Directors could be revoked without any restrictions, which means even in case of pregnancy, is complied with Article 10 of Directive 92/85/EEC and European Court case law. As regarding the question asked in case Danosa, whether a revoked pregnant sole member of the Board of Directors of a capital company should be considered a worker, the European Court accepted the opinion of independent lawyer and gave a judgement on 11 November 2010 according to which the pregnant member of the Board of Directors of a capital company should be considered worker under certain conditions and within the context of Directive 92/85/EEC, which prohibits the termination of employment contract of pregnant worker. She shall be regarded as having the status of worker for the purposes of Council Directive 92/85/EEC if that activity is carried out, for some time, under the direction or supervision of another body of that company and if, in return for those activities, the Board Member receives remuneration. It is for the 
in board member business activity may not be derogated by the fact that the board member is in employment relationship with the company based on employment contract.

national court to undertake the assessments of fact necessary to determine whether that is so in the case pending before it. According to the European Court, a dismissal due to pregnancy was unlawful as it is contrary to Article 2 paragraph 7 of Directive 76/207/EEC. Protection against dismissal granted to pregnant women and women who have given birth may not depend on formal categorization of their employment relationship under national law or on the choice made at the time of their appointment between one type of contract and another (paragraph 69). Accordingly, we can conclude that European Court extends legal protection of pregnant women outside the framework of employment relationships. The European Court answered the question in the judgement in case Danosa: "Article 10 of Directive 92/85 is to be interpreted as precluding national legislation ... which permits a member of a capital company's Board of Directors to be removed from that post without restriction, where the person concerned is a 'pregnant worker' within the meaning of that directive and the decision to remove her was taken essentially on account of her pregnancy. Even if the Board Member concerned is not a 'pregnant worker' within the meaning of Directive 92/85, the fact remains that the removal, on account of pregnancy or essentially on account of pregnancy, of a member of a Board of Directors who performs duties such as those described in the main proceedings can affect only women and therefore constitutes direct discrimination on grounds of sex, contrary to Article 2(1) and (7) and Article 3(1)(c) of Council Directive 76/207/EEC of 9 February 1976 on the implementation of the principle of equal treatment for men and women as regards access to employment, vocational training and promotion, and working conditions, as amended by Directive 2002/73/EC of the European Parliament and of the Council of 23 September 2002. It arises from the judgement in case Danosa that not only the cancellation of contract is prohibited on account of pregnancy but revocation of appointment as well. However, in the judgement in case Danosa there is no clear difference between the status and legal position of the Board Member (obtained by appointment and by accepting the appointment) and obligation and legal relationship of the Board Member with a capital company (established by concluding the contract).

As Article 71 paragraph 1 of LA contains an absolute prohibition of cancellation of employment contract during pregnancy, taking into account the judgement in case Danosa, the following should be concluded: it is prohibited to cancel the contract not just on account of pregnancy but on account of reasons not related to the pregnancy when the board member enters into the concept of worker. It is prohibited to cancel the obligation law contract on account of pregnancy to board members who do not enter that concept (as this means a direct discrimination on grounds of sex prohibited by the Anti-discrimination Act and Act on Gender Equality), but not on account of reasons not related to the pregnancy. Pursuant to Article 6 paragraph 2 of the Act on Gender Equality, less favourable treatment of women for reasons of pregnancy and maternity shall be deemed to be discrimination. It can be concluded that revocation on account of pregnancy (and maternity) means discrimination on grounds of sex in the Republic of Croatia as well, but also means that revocation during pregnancy on account of reasons not related to the pregnancy is permitted. Therefore, it is permitted to revoke the appointment during pregnancy, but not on that account.// Refer to Grgurev, I., Ceronja, P.: Opoziv imenovanja trudne članice uprave društva kapitala - spolna diskriminacija, Zbornik Pravnog fakulteta u Zagrebu. 61 (2011) , 6; p. 1881-1919 
It should be emphasized that LA correctly determines that provisions of LA related to work hours, break, daily and weekly leave may be excluded in the contract on board member management, as board members, due to their independence, determine their own work hours ${ }^{18}$. Therefore, the basic difference between the board member and worker is that the board member organizes his own work hours and is free of general assembly instructions. In case that the board member is obliged to follow the general assembly instruction or to act with the consent of supervisory board, it may not be identified with the employer's right to give instructions to workers which they are to be followed ${ }^{19}$.

Contract on conducting management duties may not be mixed with temporary service contract and order contract. Difference between the aforementioned contracts is in independence of board member in conducting management duties, independence in following the work instructions, continuity in conducting the board member duties consisting of a number of individual duties, decision making and continuous care of achieving the company interests and objectives. However, contract on conducting management duties partially regulates the manager's rights and obligations in a way that corresponds with the content of temporary service contract, i.e. with the form of temporary service contract which consists of manager's intellectual work ${ }^{20}$.

Finally, difficulty in implementing the labour law regulations into the board member duty occurs in respect of impact of termination of board member mandate on his employment relationship as well. The CA sets forth that board member mandate terminates by expiry of term, by revocation, resignation, agreement and death. In case of bankruptcy, termination of board member mandate appears as well as in all other situations which bring to termination of company business activities pursuant to Article 367 of CA. In Article 244 paragraph 2 of CA is stated that by revoking the board member or the chairman no provisions of the contract concluded with the company are breached, i.e. contractual relationship is not terminated automatically, unless dismissal and/or revocation is assumed as dismissal or termination reason. Accordingly, it is required to conclude which provisions remain enforced, e.g. provisions on prohibition of competition. Reasons for revocation are not always identical

\footnotetext{
18 Article 4 paragraph 4 and Article 88 paragraph 3 of LA

19 Grgurev, I., o. c. note No. 4, p. 53, refer to p. 90 of the same book: "Even when it is set forth by statute or decision of the company supervisory board that management board is entitled to conduct certain type of business activity only with consent of supervisory board, it does not concern the following of instructions, but the right to veto of supervisory board in order to prevent certain activity of management board."

20 Gregurić, M., Turković-Jarža., L.: Menadžerski ugovor, RRiF, No.10/2000, p. 101
} 
to the reasons for early dismissal or termination of $\operatorname{contract}^{21}$. It is required to comply the duration and termination of board membership with duration and reasons for termination of the contract concluded with a company, related to conduction of duties as board member ${ }^{22}$. Namely, if no dismissal mechanisms are foreseen, it could happen that contractual relationship still lasts regardless the board member lost his capacity, thus a revoked member is entitled to remuneration and all other contracted rights until the termination of contract (if concluded for fixed term) or until some of contracted reasons for termination of contractual relationship are realized. Therefore, it is important to regulate as many issues as possible. If it concerns the employment contract, it should take into account that the latter could be terminated, if not defined otherwise, in only one way set forth in Article 112 of LA. Such point of view is indicated by case law as well ${ }^{23}$. If it concerns a revocation of board member on account of worker's misbehaviour, his employment contract could be terminated from the same reason. In case of board member incapability to conduct management duties, pursuant to LA, the company should offer him to conduct another type of duty and only if such duty cannot be offered, his employment contract may be terminated. If board member refuses offered duty, the employment contract may be terminated only based on provisions of LA. As regarding the business-conditional dismissal, it may appear in case there is no need for conduction of management duties on account of termination of company business activities $^{24}$. One of the major issues related to the revocation of board member and termination of employment contract is severance pay issue. The case law takes the stand that as regarding the severance pay, contractual provisions are those which are primarily applicable ${ }^{25}$. As indicated in case law, the board member and company may conclude the employment contract to which the provisions of labour law will be applied; however, labour law is primarily intended for workers protection. Board member is mostly independent in man-

21 Revocation of board member appointment is possible despite good results of company management, Republic of Croatia Supreme Court judgement No. II Rev-255/00-2 and Gzz107/00-2 13.12.2000. http://sudska praksa.vsrh.hr.

22 Parać, Z.: Ugovor o obavljanju poslova članova uprave i pravni položaj nadzornog odbora, Pravo u gospodarstvu No. 7-8 /1996., p. 801.

23 Republic of Croatia Supreme Court judgement No. Revt 17/07-2, of 11.10.2007., available at http://sudskapraksa.vsrh.hr // Republic of Croatia Supreme Court judgement Revr 3/04-2 of 27.10.2004. - Employment contract with elements of management contract; the court gave advantage to contractual provision over legal provisions on termination of employment contract.

24 Republic of Croatia Supreme Court decision No. Revr 129/05-2 of 09.03.2005., available at http://sudskapraksa.vsrh.hr

25 Republic of Croatia Supreme Court decision No. Rev 519/2001-2, od 06.06.2001., available at http://sudskapraksa.vsrh.hr // www.iusinfo.hr/CaseLaws/ 
aging the company, therefore no special protection of labour law is required, e.g. as regarding the salary, work hours, termination of contract. Such legal solutions are inappropriate and inapplicable for regulation of contractual relationship between the board member and company. Precisely due to identified disadvantages (as in business practice so in case law), it is more practical to regulate such contractual relationship through obligation law contract ${ }^{26}$.

The content of management contracts can regulate all issues the parties consider to be important, e.g. amount of salary, other material rights (severance pay, profit share), ways of termination of contractual relationship, work hours, jurisdiction. However, freedom in regulating the obligation relationship is restricted by Article 2 of COA, i.e. contractual relationship may not be regulated contrary to the Republic of Croatia Constitution, forced regulations and company moral.

The case law provides for concluding the employment contract and management contract at the same time, that is, the management contract may be concluded within the framework of existing employment contract. Such solution is practically the best, as board member is thus protected through labour law standards and enjoys additional rights based on the management contract at the same time. However, every contractual relationship is specific and it should take account on regulations related to each of them. The status of board member and company can be arranged as two separate contracts, and in case of dispute between the board member and company, the employment contract will be judged by labour law principles, while the management contract by obligation law and CA principles. Nevertheless, a single contract can be concluded as the management contract, which will contain all significant provisions that regulate the manager status as company employee ${ }^{27}$.

The court jurisdiction for settling the disputes between board members and company is regulated by $\mathrm{CA}$ and Civil Procedure $\mathrm{Act}^{28}$. However, due to specifics of the contract on conducting the board member duties which can be concluded as the employment contract, obligation law contract (untitled, man-

26 Barbić, J.: Pravo društva, Knjiga II., Društvo kapitala Organizator, Zagreb, 2007, p. 451. quot.: The contract concluded between the board member and company is not particularly typified in Croatian law, even though it would be appropriate to do it in amendment to the Civil Obligations Act by introducing the duty contract which would correspond with these needs....."'//Refer to Article 4 paragraph 4 of LA

27 Gregurić. M., Turković-Jarža., L., o. c. note No. 20, p.102

28 Article 40 of CA and Article 34 paragraph 2 of the Civil Procedure Act ("Official Gazette" No. 53/91, 91/92, 112/99, 88/01 - Article 50 of the Arbitration Act, 117/03, 88/05 - Article 129 of the Act on Amendments to the Enforcement Act, 2/07 - RCCC Decision, 84/08, 96/08 RCCC Decision, 128/08, 57/11, 148/11, 25/13 and 89/14 
agement contract) or as combination of both contracts, there is a problem of division of jurisdiction as to the substance of the matter between the civil municipality courts and commercial courts. Namely, the civil municipality court is competent for employment disputes. The case law takes the stand taking primarily into consideration the freedom of contracting and regulating legal relationship between the board member and company, that is, whether the parties wanted to establish the employment or management relationship and which elements of dispute prevail, employment and legal (termination of employment contract) or elements from the management contract (remuneration, severance pay, profit share ${ }^{29}$. The severance pay issue, which mostly occurs in combination of two contracts, is resolved in different ways; there are judgements brought by municipality court and there are judgements brought by commercial court. The right to severance pay may arise from labour law standards (Article 126 of LA), but it may be determined based on the management contract as well ${ }^{30}$.

\section{CONCLUSION}

In business practice in the Republic of Croatia, in most cases the legal status of employment has been resolved by the company statute, in which the supervisory board is authorized to conclude the contracts with board members and thus regulates the board member management duties. It comes out that management contract or combination of management contract and employment

29 Republic of Croatia Supreme Court judgement Gr 1-685/03-2 of 16.9.2003., available at http://sudska praksa.vsrh.hr, "'..It can be concluded from the content of contract that the contract has elements of employment contract pursuant to provisions of LA, as well as the elements of the contract referred to in Article 247 paragraph 2 of the Companies Act (hereinafter referred to as CA) - in practice called "management contract". When taking into consideration all the aforementioned, the employment and legal elements prevail and comes out that it concerns the employment dispute, not the dispute within the meaning of Article 40 of CA between the Chairman of the Board and company which would occur in relation to carrying out the duties in company or for company."

30 Republic of Croatia Supreme Court judgement Gr 1-444/02-2 of 28.5.2002. available at http://sudska praksa.vsrh.hr. "The applicant requires from the defendant to pay him a certain amount for which the applicant thinks the latter owns him based on the contract on mutual rights and obligations (management contract) concluded on 1 August 1995, by which the rights and obligations of parties had been set forth, including the applicant's right to severance pay in case of termination of the aforementioned contract. The applicant was the board member of the company, therefore, pursuant to Article 40 of the Companies Act ("Official Gazette" No. 111/93) and within the meaning of Article 40 paragraph 2 of this Act, the Commercial Court is competent for settling the disputes which arise between the board member and company in relation to conduction of his duties in the company, i.e. for the company." RCSC Gr -125/00-2 of 27.06.2000. 
contract regulates the relationship between the board member and company in best way. Namely, the purpose of management contract concluded between the company and board members is that board members fulfil the company existence objective using their knowledge and experience. As indicated in case law analysed in this paper, the conclusion of employment contract and management contract is provided at the same time, i.e. it is provided to conclude the management contract within the framework of existing employment contract. In that case, the board member is protected based on labour law standards and enjoys additional rights based on the management contract. However, as emphasized in this paper, every contractual relationship is specific and it should take account on regulations related to each of them. The status of board member and company can be arranged as two separate contracts, and in case of dispute between the board member and company, the employment contract will be judged by labour law principles, while the management contract by obligation law and CA principles. As regarding the jurisdiction for settling the disputes arising from legal relationship between the board member and company, it should take a stand that the disputes are always subject to commercial courts regardless by which type of contract the board member and company regulate their relationship, as other party is always a company.

\section{LITERATURE:}

\section{BOOKS AND ARTICLES}

1. Čolaković, E.: Menadžerski ugovori: modeli, savjeti i praksa., 3. izmijenjeno i dopunjeno izd. Zagreb: CROMA - Hrvatsko udruženje menadžera i poduzetnika, 2009.

2. Barbić, J.: Pravo društva, Knjiga druga, Društva kapitala - dioničko društvo, VI. izdanje, Organizator 2013., Zagreb

3. Barbić, J.: Pravo društva, Knjiga druga, Društva kapitala, IV. izdanje, Organizator 2007., Zagreb

4. Barbić, J.: Pravo društva, Knjiga druga, Društva kapitala, Organizator 2000., Zagreb

5. Gorenc, V., Česić. Z., Buljan,V., Brkanić, V.: Komentar Zakona o trgovačkim društvima, IV. izmjenjena i dopunjena naklada, Zagreb RRiF - pravna biblioteka 2008.

6. Grgurev, I.: Pravna priroda i sadržaj menadžerskih ugovora, Zagreb, Radno pravo 2011.

7. Grgurev, I.: Ugovor o službi - novi imenovani ugovor? Pravo u gospodarstvu (1330-5476) 40 (2001), 4.

8. Grgurev, I., Ceronja, P.: Opoziv imenovanja trudne članice uprave društva kapitala spolna diskriminacija, Zbornik Pravnog fakulteta u Zagrebu, 61 (2011.), 6; 1881.-1919. 
9. Gregurić, M., Turković-Jarža, L.: Menadžerski ugovor, Računovodstvo, revizija i financije No. 10/2000.

10. Horak, H., Dumančić, K.: Neovisnost i nagrađivanje članova nadzornih odbora i neizvršnih direktora, Zbornik Pravnog fakulteta u Splitu, y. 48, 1/2011.

11. Potočnjak, Ž.: Pravno uređenje rada članova uprava za društva kapitala (Legal Regulation of Employment of Members of Boards in Companies), Pravo u gospodarstvu No. 3/ 2008.

12. Potočnjak, Ž. i grupa autora: Radni odnosi u Republici Hrvatskoj, Pravni fakultet u Zagrebu i Organizator, Zagreb, 2007.

13. Ruždjak, M.: Ugovor o radu i menadžerski ugovor, Pravo u gospodarstvu br. 6/1998.

14. Slakoper, Z., Buljan, V.: Trgovačka društva prema ZTD-u i domaćoj i inozemnoj sudskoj praksi i Zakon o trgovačkim društvima, TEB - Poslovno savjetovanje d.o.o. 2010.

15. Šumelj, A.: Neke osobitosti ugovora o radu, ugovora o djelu i menadžerskog ugovora, Suvremeno poduzetništvo No. 12/2003.

\section{LEGISLATION}

1. Companies Act (“Official Gazette” No. 111/93, 34/99, 121/09 - authentic interpretation, 52/00 - CCC Decision, 118/03, 107/2007, 146/08, 137/09, 152/11 - consolidated text, 111/12, 68/13 and 110/15)

2. Companies Act - consolidated text prepared by editorial office, RRiF plus d.o.o., Zagreb 2010 (appendix to Pravo i porezi magazine)

3. Labour Act (“Official Gazette” No. 149/09 and 61/11) - expired

4. Labour Act (“Official Gazette” No. 93/14)

5. Civil Obligations Act ("Official Gazette" No. 35/05, 48/08 and 78/15); (Act on Fulfilling the Monetary Obligation Terms "Official Gazette" No. 125/11 - Article 174 of COA is no longer valid)

6. Insurance Act ("Official Gazette” No. 30/15)

7. Credit Institutions Act (“Official Gazette” No. 159/13 and 19/15)

\section{JUDICIAL PRACTICE}

1. Case Revr - 666/04-2 [ 23/02/2005.] Supreme Court of the Republic of Croatia

2. Case Revr - 283/03-2 [25/09/2003.] Supreme Court of the Republic of Croatia

3. Case Revr - 680/04-5 [28/11/2006.] Supreme Court of the Republic of Croatia 
4. Case 232/09 -Dita Danosa v LKB Līzings SIA. [18/ 11/2010.] European Court

5. Case II Revr-255/00-2 and Gzz-107/00-2 [13/12/2000.] Supreme Court of the Republic of Croatia

6. Case Revr 17/07-2 [11/10/2007.] Supreme Court of the Republic of Croatia

7. Case Revr 3/04-2 [27/10/2004.] Supreme Court of the Republic of Croatia

8. Case Revr 129/05-2 [09/03/2005.] Supreme Court of the Republic of Croatia

9. Case Rev 519/2001-2 [06/06/2001.] Supreme Court of the Republic of Croatia

10. Case Gr 1-685/03-2 [16/09/2003.] Supreme Court of the Republic of Croatia

11. Case Gr 1-444/02-2 [28/05/2002.] Supreme Court of the Republic of Croatia

\section{WEB SOURCES}

1. 1.< http://sudskapraksa.hr > last accessed on 10/04/2017.

2. 2.< www.vtsrh.hr >, last accessed on 08/04/2017.

3. 3.<http://eur-lex.europa.eu/legal-content/EN/TXT/?qid=1494854250914\&uri= CELEX:62009CJ0232>, last accessed on 25/03/2017. 
